\title{
Pengaruh Konsentrasi Fungisida Mankozeb terhadap Pertumbuhan Tunas, Busuk Kering Ubi dan Susut Bobot Ubi Bibit Kentang (Solanum tuberosum L.) C.v. Granola di Ruang Penyimpanan
}

\author{
Emid Hamidin, Sumadi dan Anne Nuraeni \\ Jurusan Budidaya Pertanian Fakultas Pertanian Universitas Padjadjaran \\ Jl. Raya Bandung Ujungberung Km. 21, Bandung 40600 \\ Korespondensi: ehamidin@yahoo.com
}

\begin{abstract}
Effect of mancozeb fungicides concentration on sprout growth, tuber dry rot and tuber weight lost of seed potato (Solanum tuberosum 1.) Granola cv in storage room

Potato seeds grown in medium elevation usually came from cold storage in higher elevation. Storing potato seeds in medium altitude could induce sprout growth and also diseases infestation. The objective of this experiment was to analyze the interaction effect between mancozeb fungicides concentration and elevation of storage room on seed potato growth and dry rot infestation of seed tuber. The experimental was set up in factorial Randomized Block Design with four replications. The first factor was storage room elevation, and the second factor was the concentration of mancozeb fungicides. The results showed that there was no interaction effect between fungicides concentration and tuber storage room elevation on time of sprout emergence, percentage of sprouting tuber, percentage of tuber dry rot, and tuber weight lost. All concentration levels did not influence time of sprout emergence, percentage of sprouting tuber at 2 months after harvest (MAH) and tuber weight losses at 3 and $4 \mathrm{MAH}$. However, application of mancozeb at $3 \mathrm{~g} \mathrm{~L}^{-1}$ and $4.5 \mathrm{~g} \mathrm{~L}^{-1}$ gave higher percentage of sprouting tuber at $3 \mathrm{MAH}$ and lower percentage of tuber dry rot compared with the control one. Meanwhile, the storage room at medium elevation accelerated sprout emergence up to two weeks, increased percentage of sprouting tuber at $2 \mathrm{MAH}$, and induced tuber weight losses at 3 and $4 \mathrm{MAH}$ than that of high plain elevation. Storing seed in medium plain elevation did not increase sprouting tuber percentage at $3 \mathrm{MAH}$, and percentage of tuber with dry rot compared with that of high elevation.

Keywords: Potato, Sprouting tuber, Tuber dry rot, Tuber weight lost.

\begin{abstract}
ABSTRAK
Saat ini bibit kentang untuk penanaman di dataran medium biasanya berasal dari bibit yang disimpan di dataran tinggi dengan suhu relatif rendah. Penyimpanan di dataran medium dapat meningkatkan pertumbuhan tunas tetapi memicu perkembangan penyakit. Percobaan ini bertujuan untuk mengetahui interaksi antara konsentrasi fungisida mankozeb dan elevasi ruang simpan bibit terhadap pertumbuhan tunas dan serangan penyakit busuk kering ubi bibit. Rancangan Percobaan yang digunakan adalah Rancangan Acak Kelompok pola faktorial dengan empat ulangan. Faktor pertama adalah elevasi ruang simpan dan faktor kedua adalah konsentrasi fungisida makozeb. Hasil percobaan menunjukan tidak ada interaksi antara konsentrasi fungisida mankozeb dan elevasi ruang simpan terhadap waktu muncul tunas, persentase bibit bertunas, persentase busuk kering ubi, dan persentase susut bibit. Konsentrasi fungisida mankozeb tidak berpengaruh terhadap waktu muncul tunas, persentase ubi bibit bertunas pada 2 bulan setelah panen (BSP), dan susut bobot ubi pada 3 dan 4 BSP. Namun, aplikasi $3 \mathrm{~g} \mathrm{~L}^{-1}$ dan $4.5 \mathrm{~g} \mathrm{~L}^{-1}$ mankozeb menghasilkan persentase ubi bertunas paa $3 \mathrm{BSP}$ yang lebih tinggi dan persentase busuk kering ubi yang
\end{abstract}


lebih rendah dibandingkan dengan tanpa fungisida. Sementara itu, ruang simpan di dataran medium memberikan waktu muncul tunas yang 2 minggu lebih cepat, meningkatkan persentase ubi bertunas pada 2 BSP dan susut bobot ubi yang lebih besar pada 3 BSP dan 4 BSP dibandingkan dengan ruang simpan di dataran tinggi. Di dataran medium waktu muncul tunas 2 minggu lebih cepat, persentase ubi bertunas pada 2 BSP dan susut bobot ubi pada 3 BSP dan 4 BSP lebih besar dibandingkan dengan di dataran tinggi. Penyimpanan di dataran medium tidak meningkatkan persentase ubi berunas pada 3 BSP dan persentase busuk kering ubi dibandingkan dengan ruang simpan di dataran tinggi.

Kata kunci: Kentang, Ubi bertunas, Busuk kering ubi, Susut bobot ubi.

\section{PENDAHULUAN}

Kentang (Solanum tuberosum L.) adalah tanaman hortikultura yang sangat berpotensi sebagai sumber karbohidrat untuk menopang diversifikasi pangan dan bahan baku industri. Pada tahun 2004 areal penanaman kentang di Indonesia mencapai 67.124 ha dengan hasil rata-rata sekitar $12,7 \mathrm{t} \mathrm{ha}^{-1}$ (Badan Pusat Statistik, 2004) yang tergolong masih rendah bila dibandingkan dengan Belanda $\left(45,1 \mathrm{t} \mathrm{ha}^{-1}\right)$, Inggris $\left(41,4 \mathrm{t} \mathrm{ha}^{-1}\right)$, Amerika Serikat $\left(37,4 \mathrm{t} \mathrm{ha}^{-1}\right)$ dan Jerman (31,6 t ha $\left.{ }^{-1}\right)$ (Rubatzky \& Yamaguchi, 1995). Untuk meningkat-kan produktivitas kentang di Indonesia diperlukan bibit kentang berkualitas tinggi yang saat ini belum dapat dipenuhi oleh produsen bibit di Indonesia.

Kentang di Indonesia sebaiknya dibudidayakan di dataran tinggi pada elevasi $>1000 \mathrm{~m}$ di atas permukaan laut (dpl). Namun di daerah dataran medium (500-750 m dpl) kultivar kentang unggul seperti Granola, Atlantik, Cosima dan Desiree dapat tumbuh dengan baik (Hartus, 2001). Saat ini bibit untuk penanaman di dataran medium biasanya berasal dari bibit yang disimpan di dataran tinggi. Kemudahan penyediaan bibit kentang untuk ditanam di dataran medium perlu ditunjang oleh ruang penyimpanan bibit di dataran medium.

Selama penyimpanaan, suhu sangat berpengaruh terhadap dormansi dan pertumbuhan tunas yang diperlihatkan antara lain oleh bobot segar tunas dan panjang tunas (Horton, 1987). Selama penyimpanan berlangsung penurunan kadar sukrose yang memicu penguraian pati dan respirasi pada ubi bibit yang disimpan (Hajirezaei et al., 2003). Hasil penelitian Kazami et al. (2000) mengungkapkan bahwa pertunasan ubi bibit kentang yang disimpan pada suhu $20^{\circ} \mathrm{C}$ (setelah ditransfer dari suhu $5^{\circ} \mathrm{C}$ ) berlangsung dengan cepat dibandingkan pada $5{ }^{\circ} \mathrm{C}$. Namun demikian, susut bobot ubi kentang yang disimpan pada suhu dan kelembaban yang lebih tinggi akan lebih besar daripada di suhu dan kelembaban yang lebih rendah (Kazami et al. 2000) dan serangan penyakit busuk kering oleh Fusarium sp. lebih intensif (Semangun, 1995; Wharton et al., 2007). Fusarium sp. merupakan penyakit penting di gudang penyimpanan ubi kentang di samping Phytophthora infestans, Pythium ultimum dan Helminthosporium solani (Gachango et al., 2010).

Serangan penyakit terutama busuk kering ubi bibit yang disebabkan oleh Fusarium sp. perlu diwaspadai di ruang penyimpanan dataran medium, karena suhu tinggi di ruang simpan meningkatkan serangan Fusarium sp. (George \& Bell, 2009). Suhu ruang simpan, $25^{\circ} \mathrm{C}$, dapat menimbulkan kerusakan ubi busuk kering yang lebih intensif daripada suhu ruang simpan yang rendah (Theron \& Holtz, 1990). Mengatasi serangan ubi busuk dapat dilakukan perendaman dalam fungisida. Menurut Wharton et al. (2007) fungisida mankozeb $75 \%$ cukup efektif mengendalikan penyakit busuk ubi bibit. Caldiz et al. (2007) mengungkapkan bahwa mankozeb termasuk fungisida kontak yang efektif untuk mengendalikan penyakit yang mungkin menyerang ubi bibit kentang di gudang penyimpanan. Untuk mendukung budidaya kentang di dataran medium, perlu dipelajari efek aplikasi pestisida terhadap pertunasan, kesehatan bibit dan susut bibit yang disimpan di gudang dataran medium dan dataran tinggi. Percobaan ini bertujuan untuk mengetahui interaksi antara konsentrasi fungisida mankozeb dan elevasi ruang simpan bibit terhadap waktu muncul tunas, percentase bibit bertunas, persentase ubi bibit busuk dan persentase susut bobot ubi bibit.

\section{BAHAN DAN METODE}

Penelitian dilakukan di ruang simpan bibit Laboratorium Teknologi Benih Fakultas Pertanian Unpad Jatinangor yang terletak pada ketinggian 754 $\mathrm{m}$ di atas permukaan laut (dpl) sebagai elevasi medium 
dan di Cikole-Lembang sekitar $1250 \mathrm{~m}$ dpl sebagai elevasi tinggi. Ubi bibit kentang Granola-L 60 kelas G4 yang digunakan dalam percobaan ini dihasilkan oleh petani penangkar bibit di Pangalengan.

Model analisis berupa analisis gabungan dengan ketinggian ruang simpan sebagai faktor pertama (dataran medium, $754 \mathrm{~m} \mathrm{dpl}$, dan tinggi, $1250 \mathrm{~m}$ dpl) dan konsentrasi fungisida mankozeb 80 $\%$ (M) sebagai faktor kedua $\left(0 \mathrm{~g} \mathrm{~L}^{-1}, 1,5 \mathrm{~g} \mathrm{~L}^{-1}, 3,0 \mathrm{~g} \mathrm{~L}^{-1}\right.$ dan 4,5 $\left.\mathrm{g} \mathrm{L}^{-1}\right)$. Percobaan dirancang dalam Rancangan Acak Kelompok dengan empat ulangan.

\section{HASIL DAN PEMBAHASAN}

\section{Pertunasan}

Analisis statistik menunjukkan tidak ada pengaruh intreaksi antara konsentrasi mankozeb dengan elevasi ruang simpan terhadap waktu muncul tunas (Minggu setelah panen, MSP) dan jumlah ubi bibit bertunas. Secara mandiri, konsentrasi mankozeb tidak berpengaruh nyata terhadap waktu muncul tunas tetapi elevasi ruang simpan di dataran medium mempercepat waktu muncul tunas (Tabel 1).

Tabel 1. Pengaruh berbagai konsentrasi fungisida makozeb $80 \%$ terhadap waktu muncul tunas dan jumlah ubi bibit bertunas yang disimpan pada elevasi ruang simpan dataran medium dan dataran tinggi

\begin{tabular}{cccc}
\hline Perlakuan & Waktu muncul tunas & \multicolumn{2}{c}{ Persentase ubi bibit bertunas } \\
\cline { 4 - 4 }$($ MSP $)$ & 2 BSP & 3 BSP \\
\hline Elevasi ruang simpan (m dpl) & & & \\
754 (Dataran medium) & $11,28 \mathrm{a}$ & $86,88 \mathrm{~b}$ & $93,75 \mathrm{a}$ \\
1250 (Dataran tinggi) & $13,16 \mathrm{~b}$ & $38,13 \mathrm{a}$ & $96,88 \mathrm{a}$ \\
\hline Mankozeb $\left(\mathrm{g} \mathrm{L}^{-1}\right)$ & & \\
0,0 & $12,15 \mathrm{a}$ & $65,00 \mathrm{a}$ & $91,25 \mathrm{a}$ \\
1,5 & $12,55 \mathrm{a}$ & $53,75 \mathrm{a}$ & $93,75 \mathrm{ab}$ \\
3,0 & $12,05 \mathrm{a}$ & $65,00 \mathrm{a}$ & $97,25 \mathrm{~b}$ \\
4,5 & $12,13 \mathrm{a}$ & $66,25 \mathrm{a}$ & $98,75 \mathrm{~b}$ \\
\hline
\end{tabular}

Keterangan: Nilai rata-rata perlakuan yang diikuti huruf yang sama pada arah vertical tidak berbeda berdasarkan Uji BNT pada taraf $5 \%$

Bibit kentang disimpan di dalam keranjang bambu dengan ukuran $20 \mathrm{~cm} \times 20 \mathrm{~cm} \times 10 \mathrm{~cm}$ yang dapat memuat bibit seberat $500 \mathrm{~g}$. Bibit diberi insektisida Mipcin 50 WP pada saat masa penyimpanan 10 hari. Penyimpanan bibit dilakukan selama tiga bulan pada suhu $26,8{ }^{\circ} \mathrm{C}-29,0{ }^{\circ} \mathrm{C}$ dan kelembaban 76,8 $\%-83,3 \%$ di dataran medium dan suhu $20,5{ }^{\circ} \mathrm{C}-$ $21,0{ }^{\circ} \mathrm{C}$ dan kelembaban $79,0 \%-85,0 \%$ di dataran tinggi.

Pengamatan dilakukan terhadap pertunasan dan kesehatan ubi bibit. Variabel pertunasan yang diamati adalah waktu mucul tunas yang dilakukan seminggu sekali sejak munculnya tunas pertama hingga semua sampel bibit bertunas dan persentase ubi bibit bertunas pada dua dan tiga bulan setelah panen. Variabel kesehatan ubi yang diukur meliputi persentase ubi busuk kering akibat Fusarium sp. pada 2 bulan setelah panen (BSP) dan persentase susut bobot ubi bibit pada 3 BSP dan 4 BSP. Analisis statistik dilakukan dengan analisis ragam dengan menggunakan uji $\mathrm{F}$ dan bila terdapat perbedaan dilakukan pengujian lebih lanjut dengan uji Beda Nyata Terkecil pada taraf nyata $5 \%$.
Perbedaan waktu bertunas ini disebabkan oleh perbedaan lingkungan elevasi ruang simpan terutama suhu. Di dataran medium yang ruang lebih tinggi yaitu $26,8{ }^{\circ} \mathrm{C}-29,0{ }^{\circ} \mathrm{C}$, daripada di dataran tinggi suhu hanya $20,5^{\circ} \mathrm{C}-21,0^{\circ} \mathrm{C}$. Selama penyimpanan terjadi pematahan efek dormansi yang menyebabkan pertunasan (Kazami et al., 2000) sebagai akibat dari penguraian karbohidrat menjadi gula terlarut, meningkatnya aktivitas giberelin endogen disertai menurunnya asam absitat (ABA) (Bhargava, 1997). Hasil ini konsiten dengan penelitian terdahulu, kandungan ABA menurun secara kontinyu selama penyimpanan ubi bibit kentang (Biemelt et al., 2006). Di gudang penyimpanan dengan suhu yang lebih tinggi, metabolisme tersebut berlangsung dengan lebih cepat (Kazami et al., 2000), sehingga periode dormansi lebih pendek dan waktu pertunasan lebih cepat (Horton, 1987).

Secara mandiri konsentrasi mankozeb tidak berpengaruh terhadap jumlah ubi bibit bertunas tetapi penyimpanan di ruang simpan dataran medium menghasilkan jumlah ubi bibit bertunas yang lebih 
besar $(86,88 \%)$ daripada di dataran tinggi $(38,13 \%)$ pada 2 BSP. Pada 3 BSP, tidak ada efek elevasi ruang simpan terhadap ubi bibit bertunas tetapi $3 \mathrm{~g} \mathrm{~L}^{-1}$ dan 4,5 g $\mathrm{L}^{-1}$ mankozeb meningkatkan persentasi ubi bibit bertunas dibandingkan dengan tanpa mankozeb.

\section{Busuk Kering Ubi dan Susut Bobot Ubi Bibit}

Analisis statistik menunjukkan tidak ada pengaruh intreaksi antara konsentrasi mankozeb dengan elevasi ruang simpan terhadap persentase ubi bibit yang mengalami busuk kering dan susut bobot ubi bibit. Secara mandiri tidak ada perbedaan persentase ubi busuk kering akibat serangan Fusarium pada elevasi ruang simpan berbeda (Tabel 2). Pada percobaan ini pengaruhnya terhadap laju susut bobot ubi kentang adalah kelembaban udara di ruang simpan, makin rendah kelembaban udara makin besar susut bobot ubi. Suhu dan kelembaban yang lebih tinggi di dataran medium mengakibatkan proses penguapan dan respirasi berlangsung lebih cepat, sehingga kehilangan bobot ubi bibit lebih besar dibandingkan dengan di dataran tinggi. Hal ini sejalan dengan penelitian Singh \& Ezekiel (2003) yang mengungkapkan bahwa setelah dormansi teratasi dan pertunasan dimulai, kelembaban ruang simpan yang lebih tinggi menyebabkan lebih besarnya susut bobot ubi varietas Kufri Chandramukhi dan Kufri Jyoti. Terjadinya susut bobot ubi yang lebih besar

Tabel 2. Pengaruh berbagai konsentrasi fungisida makozeb terhadap ubi bibit busuk kering dan susut bobot ubi yang disimpan pada elevasi ruang simpan dataran medium dan dataran tinggi

\begin{tabular}{|c|c|c|c|}
\hline \multirow[t]{2}{*}{ Perlakuan } & \multirow{2}{*}{$\begin{array}{l}\text { Ubi bibit busuk kering (\%) } \\
2 \text { BSP }\end{array}$} & \multicolumn{2}{|c|}{ Susut bobot ubi (\%) } \\
\hline & & $3 \mathrm{BSP}$ & $4 \mathrm{BSP}$ \\
\hline \multicolumn{4}{|l|}{ Elevasi ruang simpan (m dpl) } \\
\hline 754 (Dataran medium) & $5,00 \mathrm{a}$ & $9,60 \mathrm{a}$ & $11,74 \mathrm{~b}$ \\
\hline 1250 (Dataran tinggi) & $1,88 \mathrm{a}$ & $6,14 \mathrm{~b}$ & $8,67 \mathrm{a}$ \\
\hline \multicolumn{4}{|l|}{ Mankozeb $\left(\mathrm{g} \mathrm{L}^{-1}\right)$} \\
\hline 0,0 & $8,75 \mathrm{~b}$ & $7,30 \mathrm{a}$ & $9,96 \mathrm{a}$ \\
\hline 1,5 & $3,75 \mathrm{ab}$ & $8,21 \mathrm{a}$ & $10,39 \mathrm{a}$ \\
\hline 3,0 & $1,25 \mathrm{a}$ & $8,57 \mathrm{a}$ & $10,83 \mathrm{a}$ \\
\hline 4,5 & $0,00 \mathrm{a}$ & $7,41 \mathrm{a}$ & $9,65 \mathrm{a}$ \\
\hline
\end{tabular}

Keterangan: Nilai rata-rata perlakuan yang diikuti huruf yang sama pada arah vertikal tidak berbeda berdasarkan Uji BNT pada taraf $5 \%$

serangan penyakit busuk kering ubi tergolong rendah, yaitu hanya mendekati $2 \%$ di dataran tinggi dan $5 \%$ di dataran medium. Aplikasi $3 \mathrm{~g} \mathrm{~L}^{-1}$ dan $4,5 \mathrm{~g} \mathrm{~L}^{-1}$ mankozeb menurunkan busuk kering ubi dibandingkan perlakuan tanpa mankozeb. Bahkan mankozeb pada konsentrasi 4,5 g $\mathrm{L}^{-1}$ meniadakan serangan Fusarium. Menurut Wharton et al. (2007) penggunaan mancozeb dengan konsentrasi 2,2 $\mathrm{g} \mathrm{L}^{-1}$ dan waktu pencelupan 10 menit yang dilanjutkan dengan pengeringan ubi bibit selama 24-48 jam cukup efektif untuk mengendalikan Fusarium.

Penyimpanan bibit di dataran medium meningkatkan susut bobot ubi bibit daripada di dataran tinggi baik pada 3 BSP maupun 4 BSP. Namun, konsentrasi fungisida tidak mempentaruhi persentase susut bobot. Perbedaan susut bobot ini terutama disebabkan oleh perbedaan suhu dan kelembaban nisbi di lingkungan elevasi ruang simpan. Menurut Kohli (2009) faktor tunggal yang paling besar setelah disimpan pada suhu $20^{\circ} \mathrm{C}$ bila dibandingan dengan suhu $5^{\circ} \mathrm{C}$ selama empat bulan penyimpanan juga dilaporkan oleh Kazami et al. (2000).

\section{SIMPULAN}

Hasil percobaan ini menunjukkan bahwa tidak terdapat pengaruh interaksi antara konsentrasi mankozeb dan elevasi ruang simpan terhadap pertunasan dan kesehatan ubi bibit kentang. Pada dua bulan masa simpan di dataran medium persentase ubi bertunas hampir mencapai $87 \%$ yang sudah dapat ditanam di lapangan. Di dataran tinggi penyimpanan 3 bulan baru cukup untuk mendapatkan ubi siap tanam karena saat itu sudah bertunas 96 \%. Pada masa simpan 3 bulan, elevasi ruang simpan tidak berpengaruh terhadap jumlah ubi bibit bertunas. Namun susut bobot di dataran tinggi lebih rendah daripada di dataran medium. Aplikasi 
mancozeb dengan konsentrasi $3 \mathrm{~g} \mathrm{~L}^{-1}$ dan 4, $5 \mathrm{~g} \mathrm{~L}^{-1}$ menghasilkan persentase ubi bibit bertunas yang lebih besar dan serangan busuk ubi yang lebih kecil daripada tanpa mankozeb.

\section{UCAPAN TERIMA KASIH}

Percobaan ini terlaksana atas bantuan dana dari DIKTI melalui program Semi Que V di Program Studi Agronomi Faperta Unpad dan bantuan penuh dari Sdri Linda Ismuwardani di lapangan. Oleh karena itu, kami ucapkan terima kasih atas bantuannya.

\section{DAFTAR PUSTAKA}

Badan Pusat Statistik. 2004. Survey pertanian tanaman sayuran dan buah-buahan di Indonesia. Jakarta. htpp://www.bps.go.id. (Diakses 6 November 2004).

Bhargava, R. 1997. Changes in absiscic and giberellic acids contents during the realise of potato seed dormancy. J. Biol. Plantarum. 39: 41-45.

Biemelt, S, M Hajirezaei, E Hentschel and U Sonnewald. 2000. Comparative analysis of abscisic acid content and starch degradation during storage of tubers harvested from different potato varieties. J. Potato Research. 43: 371-382.

Caldiz, DO, DA Rolon, J di Rico and AB Andreu. 2007. Performance of Dimethomorph + Mancozeb applied to seed potatoes in early management of late blight (Phytophthora infestans). J. Potato Research. 50: 59-70.

Direktorat Jenderal Bina Hortikultura. 2004. Kentang di Indonesia. www.deptan.co.id. (Diakses 6 November 2004).

Gachango, E, WW Kirk, PS Wharton, R Schafer and P. Tumbalam. 2010. Evaluation and Comparison of Biofungicides and Fungicides for the Control of Post Harvest Potato Tuber Diseases. Michigan Potato Disease Report. Department of Plant Pathology, Michigan State University, East Lansing, Michigan.

George, L and S Belt. 2009. Controlling Dry Rot in Seed Potatoes. Agri-Food and Biosciences
Institute. College of Agriculture. Food \& Rural Enterprise.

http.www.ruralni.gov.uk/dry_rot_leaflet_se ptember_2009_chdb.pdf (Diakses 7 November 2009.)

Hajirezaei, MR, F Börnke, M Peisker, Y Takahata, J Lerchl, A Kirakosyan and U. Sonnewald. 2003. Decreased sucrose content triggers starch breakdown and respiration in stored potato tubers (Solanum tuberosum). J. Exp. Botany. 54: 477-488.

Hartus, T. 2001. Usaha pembibitan kentang bebas virus. Penebar Swadaya, Jakarta.

Horton, D. 1987. Production, Marketing and Programs for Developing Countries. Westview Press. Boulder, Colorado.

Kazami, D, T Tsuchiya, Y Kobayashi and N Ogura. 2000. Effect of storage temperature on quality of potato tubers. J. Japanese Soc. Food Sci. Technol. 47: 851-856.

Kohli, P. (2009). Potato storage and value Preservation: TheBasics. Crosstree.Technovisors. http://crosstree.info/Documents/ Potato\%20STORAGE.pdf. (Diakses 3 Januari 2008.)

Rubatzky, VE dan M Yamaguchi. 1995. Sayuran Dunia I. Terjemahan Catur Herison. ITB. Bandung.

Semangun, H. 1996. Pengantar Ilmu Penyakit Tumbuhan. Gajah Mada University Press. Yogyakarta.

Singh, B and R Ezekiel. 2003. Influence of relative humidity on weight loss in potato tubers stored at high temperature. Indian J. Plant Physiol. 8: 141-144.

Theron, DJ and G Holtz. 1990. Effect of temperature on dry rot development of potato tubers inoculated with different Fusarium spp. J. Potato research. 33: 109117.

Wharton, P, R Hammerschmidt and W Kirk. 2007. Fusarium Dry Rot Potato Disease. Extension Bulletin E-2992. Michigan State University. East Lansing. 